\title{
Water Quality Assessment for Wastewater Reclamation Using Principal Component Analysis
}

\author{
R. X. Hao ${ }^{1, *}$, S. M. Li ${ }^{1}$ J. B. Li ${ }^{2, * *}$, Q. K. Zhang ${ }^{1,4}$, and F. Liu ${ }^{1,3}$ \\ ${ }^{1}$ Key Laboratory of Water Quality Science and Water Environment Recovery Engineering, Beijing University of Technology, Beijing 100124, \\ China \\ ${ }^{2}$ Environmental Engineering Program, University of Northern British Columbia, Prince George, BC V2N 4Z9, Canada \\ ${ }^{3}$ China Petroleum Pipeline Engineering Corporation, Langfang, Hebei 065000, China \\ ${ }^{4}$ China Archietecture Design \& Research Group, Beijing 100044, China
}

Received 5 September 2012; revised 5 March 2013; accepted 22 March 2013; published online 31 March 2013

\begin{abstract}
The water quality assessment for wastewater reclamation is usually related to many parameters. This would introduce difficulty in objectively and comprehensively evaluating the overall water quality, and affect the water reuse safety. To address this problem, a principal component analysis (PCA) method was employed in this study to identify the components that mainly affect water quality. By examining eleven indices, a large amount of water quality data of four typical wastewater reclamation treatment plants (WRTP) in northern China were collected. The PCA results indicated that four uncorrelated principal components (PC) could represent the majority of water quality information. The first PC was mainly involved with the COD index and the sensory properties of water, including chroma, turbidity, dissolved solids, and total hardness. The second $\mathrm{PC}$ included the indices of $\mathrm{NH}_{3}-\mathrm{N}$, DBP (di-n-butyl phthalate), and DEHP (Di (2-ethylhexyl) phthalate), reflecting the water reuse safety on both human health and ecological environment. The total phosphorus (TP) and iron (Fe) were included in the third PC, while the fourth PC included dissolved oxygen (DO). Based on PCA analysis, a comprehensive score of water quality was also obtained for each WRTP during each representative month, and it was found that the wastewater reclamation process could greatly affect the quality of reclaimed water. These four identified principle components can help evaluate the overall water quality, and much attention should be given to their effective monitoring and control during the operation of WRTP or the selection of appropriate treatment process.
\end{abstract}

Keywords: principal component analysis, reclaimed water, wastewater reclamation, water quality assessment

\section{Introduction}

The water resources shortage has become an exacerbating problem around the world along with the continued growth of population, accelerated industrialization and urbanization, and global climate change (Wang et al., 2012). Among various strategies to address this problem, the reclamation of municipal wastewater has been recognized as a key measure (Yi et al., 2011). The reclaimed water, namely the effluent from municipal wastewater reclamation treatment plant (WRTP), can be used for a variety of purposes. These may include scenic and landscape water use, miscellaneous urban water use (e.g., car washing, park greening, construction site water use, and street spraying), irrigation water use, and even the recharge of groundwater (Sastry and Sundaramoorthy, 1996; Yanko et al., 1999; Furumai, 2008; Carr et al., 2011). In particular, the wastewater reclamation has been widely utilized in northern China where

${ }^{*}$ Corresponding author. Tel.: +8610 67391726 8005; fax: +86 1067391648 .

E-mail address: haoruixia@bjut.edu.cn (R. X. Hao);

${ }^{* *}$ Corresponding author. Tel.: +1 250 9606397; fax: +1 2509605845 .

E-mail address: Jianbing.Li@unbc.ca (J. B. Li).

ISSN: $1726-2135$ print/1684-8799 online

C 2013 ISEIS All rights reserved. doi:10.3808/jei.201300231 the water availability is a challenging issue (Zheng et al., 2011). For example, the utilization of reclaimed water in Beijing reached 0.65 billion $\mathrm{m}^{3}$ in 2009 , accounting for about $18 \%$ of its total annual water consumption volume (Wei et al., 2011). As a result, the reclaimed water can represent an indispensable part of water resources, and its effective utilization is of critical importance.

Generally, the utilization of reclaimed water can be associated with a number of public health and environmental concerns. Many pollutants (e.g., trace toxic substances, nutrient elements, endocrine disruptors, pesticides, and personal care products) could not be thoroughly removed using conventional wastewater treatment processes (Zhao et al., 2011). This would pose potential risks on the human health and ecological system (Al-Rifai et al., 2007; Dodd et al., 2009; Singh et al., 2010; Wei et al., 2011; Yi et al., 2011). For example, Kalavrouziotis et al. (2008) observed the increased heavy metal contents in the edible plant parts of crops when treated municipal wastewater was used for irrigation. The reclaimed water with high contents of nutrient elements (e.g., N, P) can result in algal blooms in aquatic ecosystems, while the irrigation of crops using reclaimed water may also lead to excessive vegetative growth, reduced fruit set of crops, and delays in maturation (Toze, 2006; 
Rusan et al., 2007). When the reclaimed water was used for the recharge of groundwater, a long time (i.e. more than one month) travel in the subsurface was suggested for getting rid of toxic chemicals (Zhang et al., 2011). Particularly, it was reported that the estrogen (i.e. an endocrine disruptor) in aquatic environments mainly comes from the effluent of wastewater treatment plant (WWTP) (Tomšíková et al., 2012). Among various estrogens, Di (2-ethylhexyl) phthalate (DEHP) and di-n-butyl phthalate (DBP) are ubiquitous environmental contaminants that can lead to serious human health and ecological concerns. They can adversely affect the quality of vegetables through disturbing the normal physiological metabolism of plants (Yin et al., 2003). Recent studies also indicated that DEHP could induce cancer through multiple molecular signals such as DNA damage (Caldwell, 2012). Therefore, the safety associated with the reuse of reclaimed water is of fundamental importance, and this calls for an effective water quality assessment for wastewater reclamation.

The assessment of water quality has conventionally been based on the measurement of physicochemical parameters, such as the chemical oxygen demand (COD), biochemical oxygen demand $\left(\mathrm{BOD}_{5}\right)$, total organic carbon $(\mathrm{TOC})$, total nitrogen (TN), and total phosphorus (TP) (Wei et al., 2011). However, these parameters are not enough to evaluate the quality of reclaimed water. It is also necessary to include the measurement of some common estrogens (e.g., DEHP and DBP) for the purpose of wastewater reclamation security. This would lead to a wide range of water quality indices to be used in the evaluation framework. In fact, many water quality indices are included in the current wastewater reclamation standards for different applications in China, leading to the complexity of evaluating reclaimed water quality. On one hand, it is very hard for wastewater reclamation plant to monitor and analyze all of these indices during its daily operation due to the limitation of monitoring technology and cost. The incomplete monitoring data may then lead to an unauthentic water quality evaluation result. On the other hand, different wastewater treatment processes can have different removal effects on various pollutants. It is thus very difficult to choose the appropriate treatment processes since there are so many indices that need to be considered and it is not clear which index can mostly reflect the overall quality of reclaimed water. Therefore, the development of an objective water quality evaluation index framework is necessary for not only comprehensively assessing the reclaimed water quality, but also for choosing suitable wastewater treatment processes.

The comprehensive evaluation of environmental quality has been conducted using various multivariate statistical methods. In particular, principal component analysis (PCA) method is a very valuable tool, especially when there are too many variables and when correlations exist between some variables (Ouyang, 2005; Shrestha and Kazama, 2007). The PCA method can convert multiple indices into some comprehensive indices based on dimensional reduction, and can reduce calculation complexity caused by too many variables in a conventional statistical problem. For example, Kazi et al. (2009) applied cluster analysis (CA) and PCA to analyze 36 physicochemical parameters in water samples collected from a polluted lake, with CA method being used to group five sampling sites into three clusters of similar water quality characteristics, and PCA method being used for identifying chemical correlations and the factors or pollution sources responsible for water quality variations. Zhang et al. (2009) applied different multivariate statistical methods to evaluate river water quality indicated by 13 parameters, and they used CA method to group 12 monitoring months into three periods and 18 sampling sites into three groups, used discriminant analysis (DA) method to identify significant parameters for discrimination among the temporal and spatial groups, and then used PCA method to standardize water quality data sets to examine differences between these groups and identify the responsible pollution sources. However, most of the previous studies using PCA method were focused on river water, lake water, and irrigation water, while less attention has been put on the reclaimed water (Mandal et al., 2008; Peiris et al., 2010; Peldszus et al., 2011). In fact, although many indices have been selected for monitoring the effluent quality of WRTP and used in the wastewater reclamation standards, some of them are correlated to each other. This would lead to the overlap of information for water quality assessment (Guimet et al., 2004; Primpas et al., 2010). This kind of information overlap can be addressed through reducing the insignificant components from the evaluation index system. The objective of this study was then to develop a simplified water quality evaluation index system for wastewater reclamation. The monitoring data collected from four WRTPs in northern China were analyzed, and the PCA method was applied for identifying the major indices that can fully and objectively reflect the reclaimed water quality. This would be valuable for objectively comparing the performances of different wastewater treatment processes and ensuring the safe utilization of reclaimed water.

\section{Materials and Methods}

\subsection{Data Collection for Physicochemical Parameters}

Nine routine water quality indices were monitored on a daily basis within four municipal wastewater reclamation treatment plants (WRTPs) in northern China, and the daily monitoring data of these indices within four representative months of 2010 (i.e. January, April, July, and October) were directly obtained from these WRTPs in this study. The nine indices included chroma, turbidity, dissolved solids, total hardness, iron, DO, COD, total phosphorus, and ammonia nitrogen. The daily values of these indices in each month were then averaged to obtain the monthly value for water quality assessment. The influents of these WRTPs came from the effluents of municipal wastewater treatment plants (WWTPs), while the reclaimed water were used for different miscellaneous urban water uses. Thus, heavy metals were not included in the indices. These four treatment plants are located in a city of northern China, and they vary in treatment capacity, treatment process, and effluent usage. Figure 1 shows the process flow of each WRTP, and Table 1 lists their information.

\subsection{Analysis of Estrogens in Reclaimed Water}

In addition to the physicochemical data, the measurements of estrogens (e.g., DEHP and DBP) in reclaimed water were 

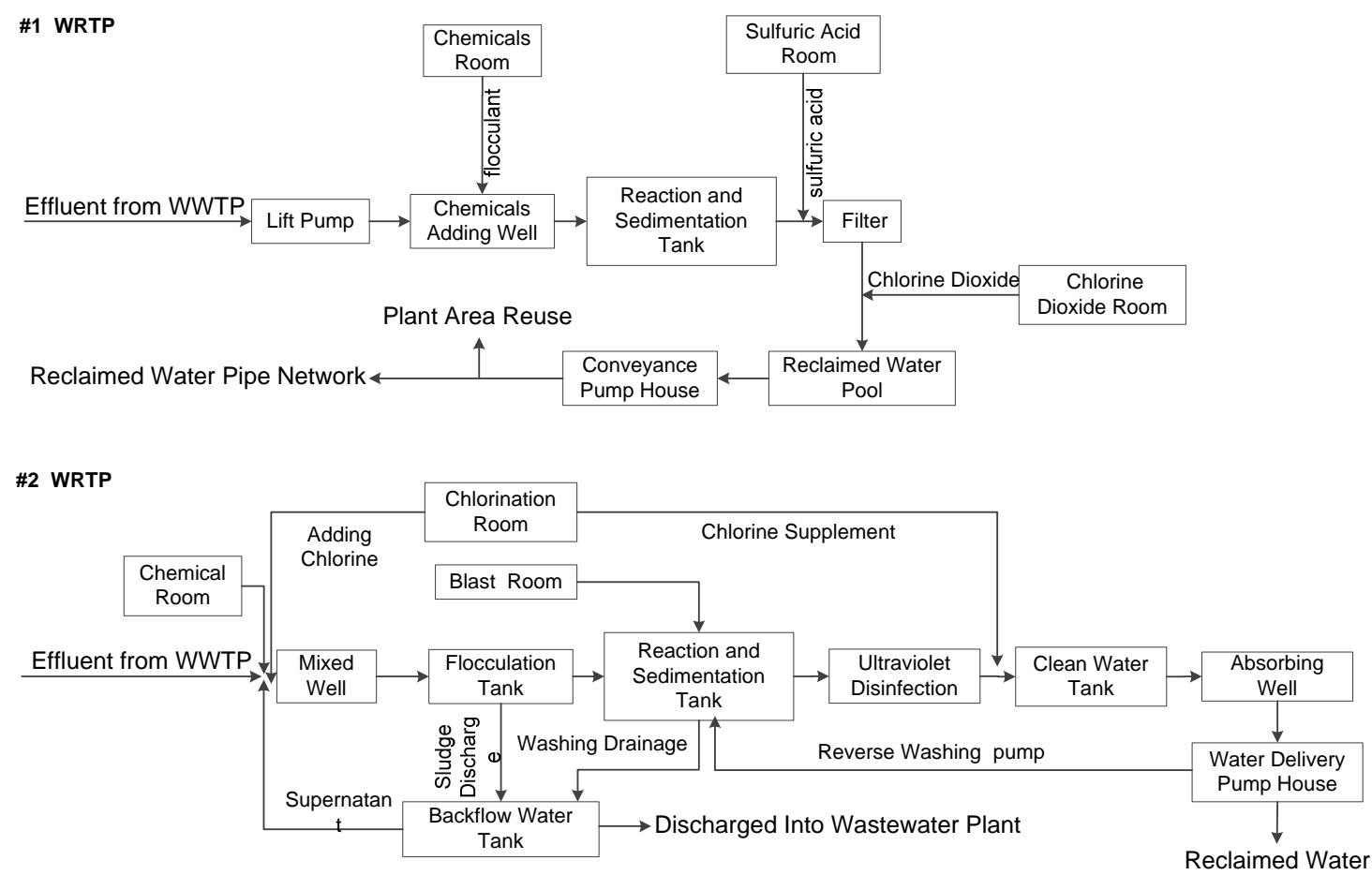

\#3 WRTP

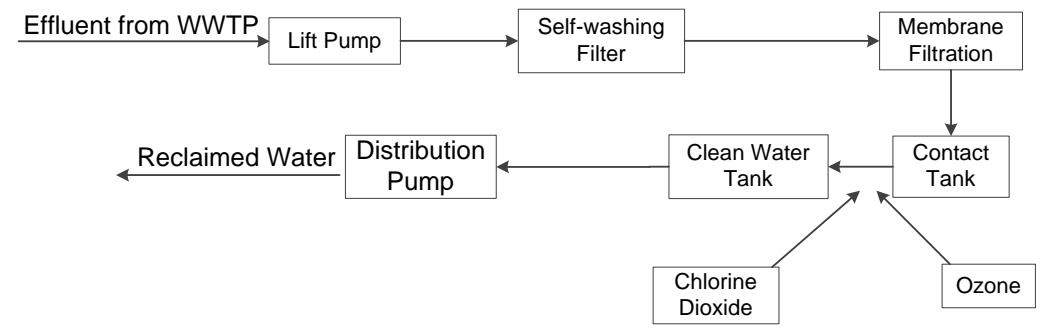

\#4 WRTP

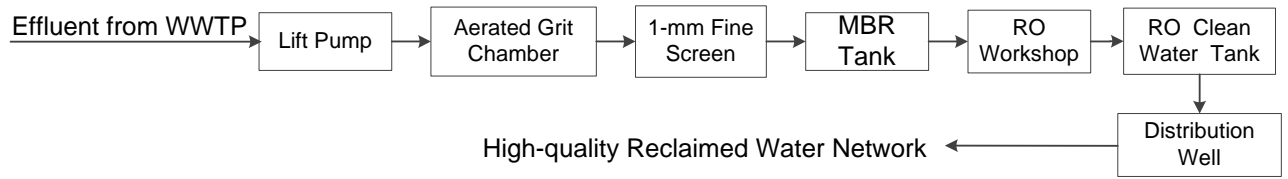

Figure 1. Process flow charts of four wastewater reclamation treatment plants (WRTP).

also conducted in this study since they are of public health concerns. As the water quality indices for optional control, DEHP and DBP are listed in the current national wastewater reclamation standards in China, including "the reuse of urban recycling water - water quality standard for scenic environmental use (GB/T 18921 - 2002)" and "the reuse of urban recycling water - water quality standard for groundwater recharge(GB/T 19772 - 2005)". However, these indices have still not been monitored on a daily basis in many WRTPs. As a result, the reclaimed water samples were collected from the four representative WRTPs in 2010, and were used to analyze DEHP and DBP concentrations. A total of $3 \sim 5$ water quality samples were collected from each WRTP within each representative month, and the samples were analyzed for DEHP and DBP concentrations, while the average concentration of these samples was used as the monthly concentration of DEHP or DBP for each WRTP within that particular month. The analysis was conducted using SPE-GC-MS based on the methods outlined in previous literatures (Suzuki et al., 2001; Eaton et al., 2005). The equipments used for analysis include gas chromatography mass spectrometry (GC-MS) (Agilent, USA), HP-5UI capillary column (30 m $\times 0.25 \mathrm{~mm} \times 0.25 \mu \mathrm{m})$ with maximum use temperature of 325 ${ }^{\circ} \mathrm{C}$ (Agilent, USA), solid phase extraction (SPE) equipment and sample introduction device (Supelco, USA), nitrogen evaporator (Organomation Co. Ltd., USA), pipette (Gilson Co. Ltd., France), and ultra-pure water device (Millipore, USA). The consumables mainly included the DBP and DEHP standard solutions (Institute for Reference Materials of SEPA, China), chromatography grade methanol (Siyou Technology Co. Ltd., China), solid phase extraction column of $30 \mu \mathrm{m} \times 60 \mathrm{mg} \times 3 \mathrm{cc}$ 
Table 1. Information of the Wastewater Reclamation Treatment Plants (WRTPs)

\begin{tabular}{|c|c|c|c|c|}
\hline $\begin{array}{l}\text { Plant } \\
\#\end{array}$ & $\begin{array}{l}\text { Capacity } \\
\left(\mathrm{m}^{3} / \mathrm{d}\right)\end{array}$ & Treatment & Reclamation treatment process & Reclaimed water use \\
\hline 1 & 5,000 & $\mathrm{~A} / \mathrm{A} / \mathrm{O}$ & $\begin{array}{l}\text { Coagulation, sedimentation, and filtration, } \\
\text { followed by } \mathrm{ClO}_{2} \text { disinfection }\end{array}$ & Urban landscape greening, toilet flushing \\
\hline 2 & 40,000 & SBR & $\begin{array}{l}\text { Micro-flocculation and filtration, followed } \\
\text { by ultraviolet (UV) and } \mathrm{ClO}_{2} \text { disinfection }\end{array}$ & $\begin{array}{l}\text { Urban landscape greening, toilet flushing, urban scenic } \\
\text { lake water replenishment, urban road sprinkling, } \\
\text { industrial circulating cooling water }\end{array}$ \\
\hline 3 & 80,000 & $\begin{array}{l}\text { inverted } \\
\mathrm{A} / \mathrm{A} / \mathrm{O}\end{array}$ & $\begin{array}{l}\text { Ultra-filtration membrane treatment and } \\
\text { ozone decoloration, followed by } \mathrm{ClO}_{2} \\
\text { disinfection }\end{array}$ & $\begin{array}{l}\text { Landscape water use in parks, toilet flushing, water } \\
\text { replenishment for lake or river, urban miscellaneous } \\
\text { Water consumption }\end{array}$ \\
\hline 4 & 10,000 & $\begin{array}{l}\mathrm{A} / \mathrm{A} / \mathrm{O}+ \\
\mathrm{MBR}\end{array}$ & Reverse osmosis (RO) treatment process & Landscape water use in a theme park \\
\hline
\end{tabular}

* A/A/O - anaerobic-anoxic-oxic; SBR - sequencing batch reactor; MBR - membrane bio-reactor.

Table 2. Reclaimed Water Quality Data of Four Wastewater Reclamation Treatment Plants (WRTPs)

\begin{tabular}{|c|c|c|c|c|c|c|c|c|c|c|c|}
\hline $\begin{array}{l}\text { WRTP } \\
\text { No. }\end{array}$ & $\begin{array}{l}\text { Chroma } \\
\left(\mathrm{X}_{1}\right) \\
\text { (degree) }\end{array}$ & $\begin{array}{l}\text { Turbidity } \\
\left(\mathrm{X}_{2}\right) \\
(\mathrm{NTU})\end{array}$ & $\begin{array}{l}\mathrm{DS}^{*} \\
\left(\mathrm{X}_{3}\right) \\
(\mathrm{mg} / \mathrm{L})\end{array}$ & $\begin{array}{l}\mathrm{TH}^{*} \\
\left(\mathrm{X}_{4}\right) \\
(\mathrm{mg} / \mathrm{L})\end{array}$ & $\begin{array}{l}\text { Iron } \\
\left(\mathrm{X}_{5}\right) \\
(\mathrm{mg} / \mathrm{L})\end{array}$ & $\begin{array}{l}\text { DO index } \\
\left(\mathrm{X}_{6}\right) \\
(\mathrm{mg} / \mathrm{L})\end{array}$ & $\begin{array}{l}\mathrm{COD} \\
\left(\mathrm{X}_{7}\right) \\
(\mathrm{mg} / \mathrm{L})\end{array}$ & $\begin{array}{l}\mathrm{TP}^{*} \\
\left(\mathrm{X}_{8}\right) \\
(\mathrm{mg} / \mathrm{L})\end{array}$ & $\begin{array}{l}\mathrm{NH}_{3}-\mathrm{N}^{*} \\
\left(\mathrm{X}_{9}\right) \\
(\mathrm{mg} / \mathrm{L})\end{array}$ & $\begin{array}{l}\mathrm{DBP} \\
\left(\mathrm{X}_{10}\right) \\
(\mu \mathrm{g} / \mathrm{L})\end{array}$ & $\begin{array}{l}\text { DEHP } \\
\left(X_{11}\right) \\
(\mu \mathrm{g} / \mathrm{L})\end{array}$ \\
\hline \multirow[t]{4}{*}{$\# 1$} & 9 & 1.17 & 574 & 188 & 0.091 & 3.40 & 35.59 & 0.084 & 11.9 & 5.59 & 4.93 \\
\hline & 11 & 1.06 & 553 & 242 & 0.061 & 6.72 & 26 & 0.188 & 6.06 & 2.48 & 2.16 \\
\hline & 9 & 0.85 & 586 & 257 & 0.054 & 6.84 & 16.3 & 1.34 & 0.509 & 2.89 & 0.46 \\
\hline & 7 & 0.73 & 613 & 220 & 0.030 & 6.29 & 15.4 & 0.173 & 0.359 & 2.39 & 0.82 \\
\hline \multirow[t]{4}{*}{$\# 2$} & 27 & 1.97 & 1470 & 502 & 0.138 & 3.39 & 39.26 & 0.447 & 2.8 & 4.45 & 3.99 \\
\hline & 23 & 1.00 & 1380 & 462 & 0.108 & 6.12 & 29 & 0.581 & 1.8 & 1.8 & 1.57 \\
\hline & 24 & 1.03 & 1340 & 433 & 0.153 & 6.59 & 30.3 & 0.344 & 3.42 & 1.84 & 0.89 \\
\hline & 21 & 1.78 & 1560 & 499 & 0.135 & 5.36 & 28.3 & 0.157 & 1.21 & 2.57 & 1.28 \\
\hline \multirow[t]{4}{*}{$\# 3$} & 9 & 0.28 & 647 & 303 & 0.07 & 2.69 & 30.62 & 0.073 & 1.77 & 3.22 & 2.91 \\
\hline & 13 & 0.24 & 600 & 282 & 0.073 & 0.91 & 21.2 & 0.17 & 2.22 & 1.97 & 1.51 \\
\hline & 6 & 0.30 & 563 & 269 & 0.063 & 2.62 & 14 & 0.672 & 0.939 & 4.51 & 1.88 \\
\hline & 6 & 0.31 & 645 & 306 & 0.106 & 0.12 & 15 & 0.555 & 1.6 & 4.47 & 1.77 \\
\hline \multirow[t]{4}{*}{$\# 4$} & 3 & 0.21 & 0 & 0.00 & 0.000 & 3.80 & 5.00 & 0.010 & 0.377 & 2.29 & 0.42 \\
\hline & 6 & 0.38 & 30 & 8.66 & 0.241 & 4.26 & 5.00 & 0.015 & 0.090 & 2.4 & 0.84 \\
\hline & 4 & 0.13 & 0 & 0.00 & 0.000 & 4.27 & 12.60 & 0.010 & 0.025 & 1.74 & 1.1 \\
\hline & 3 & 0.16 & 97 & 25.30 & 0.284 & 6.85 & 5.00 & 0.010 & 0.025 & 4.04 & 1.66 \\
\hline
\end{tabular}

* DS - dissolved solids; $\mathrm{TH}$ - total hardness; $\mathrm{TP}$ - total phosphorus; $\mathrm{NH}_{3}-\mathrm{N}$ - ammonia nitrogen.

(Waters Co. Ltd., USA), nitrogen and helium with purity of 99.999\% (Zhaoge Gas Technology Co. Ltd, China), and ultrafiltration membrane of $0.45 \mu \mathrm{m}$ (Dongke Equipment Technology Co. Ltd., China).

The solid phase extraction (SPE) method was used for the pretreatment of reclaimed water sample, and the HLB extraction column was activated by $6 \mathrm{~mL}$ of methanol and distilled water before use. The reclaimed water sample was firstly filtered through a fiber membrane filter with an average pore diameter of $0.45 \mu \mathrm{m}$, and about $100 \mathrm{~mL}$ of filtrate went through the HLB extraction column at a flow rate of $2 \sim 3 \mathrm{~mL} / \mathrm{min}$ under vacuum pressure. The adsorbed DBP and DEHP were then quantitatively eluted from the extraction column into a centrifuge tube with $9 \mathrm{~mL}$ of eluent that was the mixed ether and methanol (i.e. mixing ratio of 95:5). The obtained liquid was then blown off with high-purity nitrogen until its volume was about $1 \mathrm{~mL}$, and the volume was finally adjusted to exactly 1 $\mathrm{mL}$. In terms of the operating conditions of GC, the carrier gas (helium) flow rate was $1.0 \mathrm{~mL} / \mathrm{min}$, and the injection port temperature was $280{ }^{\circ} \mathrm{C}$. The temperature program comprised of four phases. Initially the temperature was set at $50{ }^{\circ} \mathrm{C}$ for 0.75 $\mathrm{min}$, and it was then ramped to $150{ }^{\circ} \mathrm{C}$ at a rate of $20^{\circ} \mathrm{C} / \mathrm{min}$. After that, it was ramped to $260^{\circ} \mathrm{C}$ and was held for $3 \mathrm{~min}$. Finally, it was ramped to $280{ }^{\circ} \mathrm{C}$ at a rate of $5{ }^{\circ} \mathrm{C} / \mathrm{min}$. The sampling method was splitless injection with injection volume of 1 $\mu \mathrm{L}$. In terms of the mass spectrometer conditions, the ion source temperature was $230{ }^{\circ} \mathrm{C}$ and the interface temperature was $280{ }^{\circ} \mathrm{C}$. The electron impact energy was $70 \mathrm{eV}$ and the electron multiplier voltage was $1718 \mathrm{eV}$. The selected ion monitoring (SIM) was chosen as the scanning mode with mass-to-charge ratio $(\mathrm{m} / \mathrm{z})$ of the characteristic ions of DBP (e.g., $\mathrm{m} / \mathrm{z}$ of 149 , 205, and 223) and DEHP (e.g., m/z of 149, 167, and 279), respectively. The solvent delay was $4.8 \mathrm{~min}$.

\subsection{Procedures of Principal Component Analysis}

The principal component analysis (PCA) has been designed to convert a large dataset of the original correlated variables into a smaller set of new and uncorrelated variables (i.e. principal components). Through data reduction, it provides in- 
Table 3. Standardized Matrix (Y) of the Original Data Set of Reclaimed Water Quality Variables

\begin{tabular}{llllllllllll}
\hline WRTP No. & $\mathrm{Y}_{1}$ & $\mathrm{Y}_{2}$ & $\mathrm{Y}_{3}$ & $\mathrm{Y}_{4}$ & $\mathrm{Y}_{5}$ & $\mathrm{Y}_{6}$ & $\mathrm{Y}_{7}$ & $\mathrm{Y}_{8}$ & $\mathrm{Y}_{9}$ & $\mathrm{Y}_{10}$ & $\mathrm{Y}_{11}$ \\
\hline$\# 1$ & -0.290 & 0.771 & -0.177 & -0.357 & -0.121 & -0.463 & 1.359 & -0.614 & 3.205 & 2.130 & 2.544 \\
& -0.039 & 0.580 & -0.217 & -0.045 & -0.507 & 1.090 & 0.493 & -0.321 & 1.276 & -0.468 & 0.320 \\
& -0.290 & 0.216 & -0.154 & 0.042 & -0.596 & 1.146 & -0.382 & 2.928 & -0.556 & -0.126 & -1.045 \\
& -0.541 & 0.009 & -0.102 & -0.172 & -0.905 & 0.889 & -0.464 & -0.363 & -0.606 & -0.544 & -0.756 \\
& 1.970 & 2.156 & 1.543 & 1.456 & 0.482 & -0.467 & 1.690 & 0.410 & 0.200 & 1.177 & 1.789 \\
& 1.467 & 0.476 & 1.370 & 1.225 & 0.097 & 0.809 & 0.764 & 0.788 & -0.130 & -1.036 & -0.154 \\
& 1.593 & 0.528 & 1.293 & 1.058 & 0.675 & 1.029 & 0.881 & 0.119 & 0.405 & -1.003 & -0.700 \\
& 1.216 & 1.827 & 1.716 & 1.439 & 0.444 & 0.454 & 0.701 & -0.408 & -0.325 & -0.393 & -0.387 \\
& -0.290 & -0.771 & -0.037 & 0.307 & -0.391 & -0.795 & 0.910 & -0.645 & -0.140 & 0.150 & 0.922 \\
& 0.212 & -0.840 & -0.127 & 0.186 & -0.352 & -1.627 & 0.060 & -0.372 & 0.009 & -0.894 & -0.202 \\
& -0.667 & -0.736 & -0.198 & 0.111 & -0.481 & -0.827 & -0.590 & 1.044 & -0.414 & 1.228 & 0.095 \\
& -0.667 & -0.719 & -0.041 & 0.324 & 0.071 & -1.997 & -0.500 & 0.714 & -0.196 & 1.194 & 0.007 \\
& -1.044 & -0.892 & -1.279 & -1.443 & -1.290 & -0.276 & -1.402 & -0.823 & -0.600 & -0.627 & -1.077 \\
& -0.667 & -0.597 & -1.221 & -1.392 & 1.805 & -0.061 & -1.402 & -0.809 & -0.695 & -0.535 & -0.740 \\
& -0.918 & -1.030 & -1.279 & -1.443 & -1.290 & -0.056 & -0.716 & -0.823 & -0.716 & -1.087 & -0.531 \\
& -1.044 & -0.978 & -1.092 & -1.296 & 2.358 & 1.151 & -1.402 & -0.823 & -0.716 & 0.835 & -0.082 \\
\hline
\end{tabular}

formation on the most meaningful parameters that can describe a whole data set with minimum loss of original information (Iscen et al., 2008). The principal components are weighted linear combinations of original variables, with the first principal component representing the largest variability of the original data set, and the second component representing the next largest variance that is orthogonal to the first component (Deb et al., 2008). The PCA method involves a number of steps (Ouyang, 2005), including (1) listing the data matrix with original variables $X_{i}$ of water quality indices; (2) transforming matrix $X_{i}$ into a standardized matrix $Y_{i}$ (i.e. with zero mean and unit variance) using Equation (1) so that they all have equal weights in the analysis; (3) using Equations (2 3) to calculate the covariance matrix $R$ of $Y_{i}$ (i.e. the correlation coefficient matrix of $X_{i}$ ), the eigenvalues $\left(\lambda_{i}\right)$, and the corresponding eigenvector $\left(L_{i}\right)$; (4) identifying the principal components and discarding any components that only account for a small portion of the variation in the data set, while the cumulative percentage variance of greater than $80 \%$ was used as a criterion in this study to select the principle components; $(5)$ calculating the score $\left(Z_{i}\right)$ of the principle components and the comprehensive score $(Z)$ of each WRTP using Equations $(4 \sim 5)$. The related equations are:

$Y_{i}=\frac{X_{i}-E\left(X_{i}\right)}{\sqrt{D\left(X_{i}\right)}}$

$\left|R-\lambda_{i} E\right|=0$

$L_{i}=\frac{B_{i}}{\sqrt{\lambda_{i}}}$

$Z_{i}=L_{i} \times Y_{i}$

$Z=\sum_{i=1}^{m} d_{i} \times Z_{i}$ where $\mathrm{E}\left(X_{i}\right)$ is the average value of the original data $X_{i}, \mathrm{D}\left(X_{i}\right)$ is the variance of $X_{i}, \mathrm{E}$ is the unit matrix, $\mathrm{B}_{\mathrm{i}}$ is the component loading matrix value, $d_{i}$ is variance contribution, and $Z_{i}$ is the comprehensive score of the principle component.

A total of 11 water quality indices were included in the water quality assessment of reclaimed water, including chroma, turbidity, dissolved solids (DS), total hardness (TH), iron, DO, COD, total phosphorus (TP), and ammonia nitrogen $\left(\mathrm{NH}_{3}-\mathrm{N}\right)$, DBP, and DEHP. Among them, the first four indices (i.e. chroma, turbidity, DS, and TH) can reflect the sensory property of reclaimed water. The COD index can reflect the organic pollutant content, while the indices of TP and $\mathrm{NH}_{3}-\mathrm{N}$ can represent the nutrient content of reclaimed water. The DBP and DEHP indices reflect the estrogen content of reclaimed water, indicating the water reuse safety on human health and ecosystem. Except for DO concentration, the higher value of these indices can indicate worse reclaimed water quality. In this study, some water quality samples were observed to have oversaturated dissolved oxygen concentrations. To maintain the consistency with other indices in terms of the correlation with water quality, the DO index was calculated as $\left[\left(\mathrm{DO}_{\mathrm{S}}+4\right)-\mathrm{DO}\right](\mathrm{mg} / \mathrm{L})$, where $\mathrm{DO}_{\mathrm{S}}$ is the saturated DO concentration at a certain temperature $(\mathrm{mg} / \mathrm{L})$, and DO is the measured DO concentration $(\mathrm{mg} / \mathrm{L})$. Consequently, a higher DO index indicates a worse reclaimed water quality.

\section{Results and Discussions}

\subsection{Reclaimed Water Quality Data}

Table 2 lists the matrix of the original water quality variables $\left(X_{i}\right)$, where the four rows of data for each wastewater reclamation treatment plant (WRTP) represent the water quality indices within four different months in 2010. It can be found that the water quality indices vary significantly among different wastewater reclamation treatment plants. Seasonal variations of reclaimed water quality were also observed for the same treatment plant. For example, the maximum $\mathrm{NH}_{3}-\mathrm{N}$ con- 
Table 4. Total Variance Explained

\begin{tabular}{|c|c|c|c|c|c|c|}
\hline \multirow{2}{*}{ Component } & \multicolumn{3}{|c|}{ Initial eigenvalue } & \multicolumn{3}{|c|}{ Extraction sums of squared loadings } \\
\hline & Total & $\%$ of variance & Cumulative $\%$ & Total & $\%$ of variance & Cumulative $\%$ \\
\hline 1 & 4.789 & 43.53 & 43.53 & 4.789 & 43.53 & 43.53 \\
\hline 2 & 2.384 & 21.67 & 65.20 & 2.384 & 21.67 & 65.20 \\
\hline 3 & 1.276 & 11.60 & 76.80 & 1.276 & 11.60 & 76.80 \\
\hline 4 & 1.058 & 9.62 & 86.42 & 1.058 & 9.62 & 86.42 \\
\hline 5 & 0.870 & 7.91 & 94.33 & & & \\
\hline 6 & 0.275 & 2.50 & 96.83 & & & \\
\hline 7 & 0.170 & 1.55 & 98.37 & & & \\
\hline 8 & 0.126 & 1.15 & 99.52 & & & \\
\hline 9 & 0.036 & 0.33 & 99.85 & & & \\
\hline 10 & 0.012 & 0.11 & 99.95 & & & \\
\hline 11 & 0.005 & 0.05 & 100.00 & & & \\
\hline
\end{tabular}

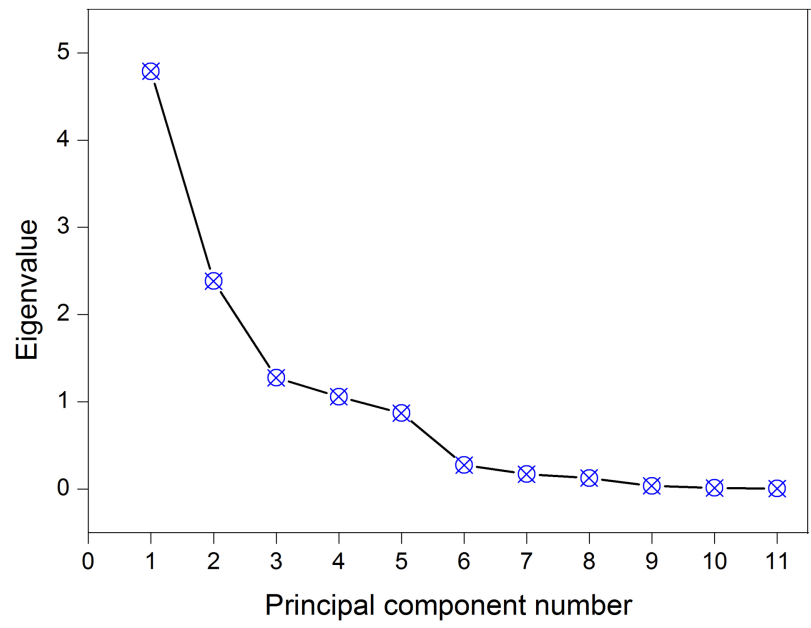

Figure 2. Scree plot of the eigenvalues of principal components.

centration in reclaimed water observed in each WRTP ranged from 0.377 to $11.9 \mathrm{mg} / \mathrm{L}$ for the four WRTPs, and the $\mathrm{NH}_{3}-\mathrm{N}$ concentration ranged from 0.359 to $11.9 \mathrm{mg} / \mathrm{L}$ for WRTP \#1 during the four different months. For WRTP \#1, the TP and $\mathrm{NH}_{3}-\mathrm{N}$ concentrations in reclaimed water were observed to be 0.084 and $11.9 \mathrm{mg} / \mathrm{L}$ in January and 1.34 and $0.509 \mathrm{mg} / \mathrm{L}$ in July, respectively. It was noted that the reclaimed water quality standard in China was $\leq 5.0 \mathrm{mg} / \mathrm{L}$ for $\mathrm{NH}_{3}-\mathrm{N}$ and $\leq 1.0$ $\mathrm{mg} / \mathrm{L}$ for TP as stipulated in the "Standards of Reclaimed Water Quality" (SL368-2006) when the reclaimed water was used for landscape water replenishment in river. Such variation of different water quality parameters may bring difficulties in objectively evaluating the overall quality of reclaimed water.

\subsection{Principal Component Analysis}

The SPSS statistical analysis software was used to calculate the standardized matrix $\left(Y_{i}\right)$ of the original data set of water quality variables $\left(X_{i}\right)$ based on Equation (1) (Table 3). The eigenvalue greater than 1 was taken as criterion for the extraction of principal components required to explain the sources of variances in the data (Iscen et al., 2008). Figure 2 presents the scree plot that shows the relationship between every com- ponent in sequence and its eigenvalue. Generally, an inflection point could be found in the scree plot, and the component sequence number corresponding to that inflection point represents the total number of principal components. As seen from Figure 2 , the inflection point occurred at the component sequence number of 4 after which the eigenvalues were less than 1:

$$
L=\left[\begin{array}{ccccc} 
& L_{1} & L_{2} & L_{3} & L_{4} \\
y_{1} & 0.403 & -0.236 & 0.083 & -0.049 \\
y_{2} & 0.402 & -0.085 & 0.159 & -0.035 \\
y_{3} & 0.419 & -0.210 & -0.043 & 0.060 \\
y_{4} & 0.409 & -0.178 & -0.187 & 0.113 \\
y_{5} & 0.039 & 0.002 & 0.682 & 0.543 \\
y_{6} & 0.030 & -0.353 & 0.467 & -0.103 \\
y_{7} & 0.427 & 0.099 & -0.053 & -0.231 \\
y_{8} & 0.120 & -0.212 & -0.479 & 0.533 \\
y_{9} & 0.233 & 0.413 & 0.100 & -0.302 \\
y_{10} & 0.109 & 0.505 & -0.030 & 0.496 \\
y_{11} & 0.261 & 0.506 & 0.064 & -0.018
\end{array}\right]
$$

The eigenvalues for different components, percentage variance counted, cumulative percentage variance, and component loadings were also calculated using SPSS software based on Equations $(2 \sim 3)$, and Tables $4 \sim 5$ present the results. Equation (6) presents the eigenvector L. In Table 4, "Total”, " \% of Variance" and "Cumulative \%" represent the eigenvalue, variance contribution, and cumulative variance contribution, respectively. As shown in Table 4, the cumulative variance contribution of the first four components was $86.42 \%$. As a result, these four components could have reflected enough water quality information of the original data set, and can be used to analyze and evaluate the quality of reclaimed water from different WRTPs. The component loadings of these four principle components (PC) are presented in Figure 3. The first principle component had a variance contribution of $43.53 \%$. By observing the magnitude of component loadings shown in Figure 3, this principal component mainly included chroma, turbidity, dissolved solids, total hardness, and COD. The second principal component had a variance contribution rate of $21.67 \%$, and it main- 
Table 5. Component Loading Matrix

\begin{tabular}{lllll}
\hline Water quality parameters & \multicolumn{3}{c}{ Component } \\
\cline { 2 - 5 } & 1 & 2 & 3 & 4 \\
\hline Chroma & 0.881 & -0.365 & 0.094 & -0.050 \\
Turbidity & 0.881 & -0.131 & 0.179 & -0.036 \\
Dissolved solids & 0.916 & -0.324 & -0.049 & 0.062 \\
Total Hardness & 0.894 & -0.274 & -0.212 & 0.116 \\
Iron & 0.086 & 0.002 & 0.771 & 0.559 \\
DO & 0.065 & -0.546 & 0.528 & -0.106 \\
COD & 0.935 & 0.152 & -0.060 & -0.238 \\
Total phosphorus & 0.262 & -0.328 & -0.541 & 0.548 \\
NH $H_{3}$ & 0.510 & 0.638 & 0.112 & -0.311 \\
DBP & 0.238 & 0.779 & -0.034 & 0.510 \\
DEHP & 0.571 & 0.782 & 0.072 & -0.018 \\
\hline
\end{tabular}
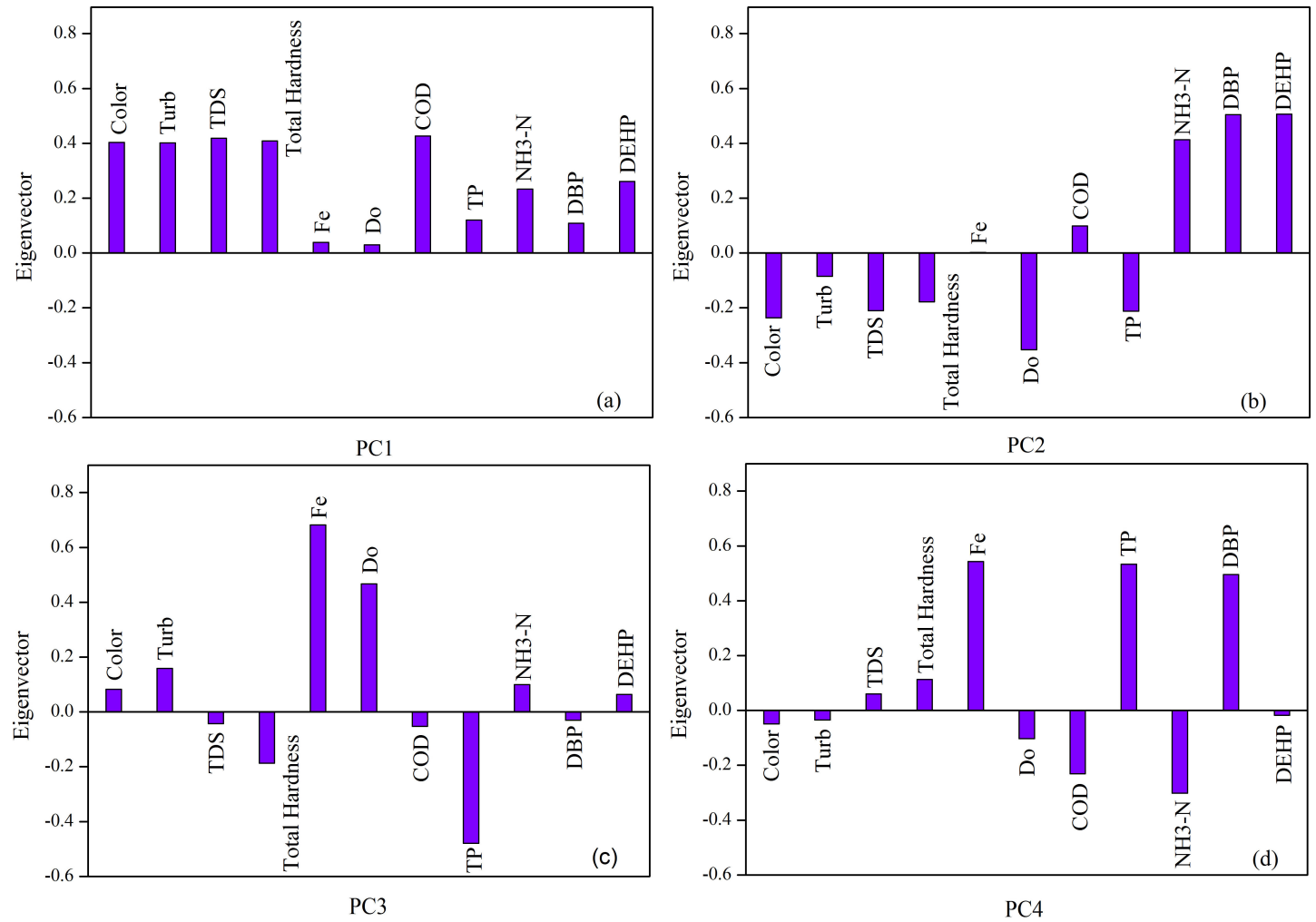

Figure 3. Component loadings for the four principal components (PC).

ly included the indices of $\mathrm{NH}_{3}-\mathrm{N}, \mathrm{DBP}$, and DEHP. The variance contribution of the third principal component was $11.60 \%$, with the parameters of TP and Fe being mainly involved. The fourth principal component had a variance contribution of $9.62 \%$, and DO was its mainly involved water quality index.

The identification of these four principal components were of important significance in the reuse of reclaimed water. In the first principle component, chroma, turbidity, dissolved solids, and total hardness are the sensory property indices, while COD could reflect the concentration of organic pollutants in reclaimed water. The control of these indices should be a premise of the reuse of reclaimed water (e.g., clear and no odor). In the second principle component, DBP and DEHP are two types of indices involving the safety of ecology and human health, and the $\mathrm{NH}_{3}-\mathrm{N}$ tends to cause water eutrophication that is harmful to fish and some other aquatic organisms. They should be given much attention due to the safety concerns of the reuse of reclaimed water. In the third principle component, the Fe index had important influence on the color of reclaimed water, and the total phosphorus can be contributed to water eutrophication. Attention should be given to these parameters especially when the reclaimed water was used to recharge river and lake environment. In the fourth principle component, the DO index could reflect not only the capability of water self-purification but 
Table 6. Principal Component Scores for Each Wastewater Reclamation Treatment Plant (WRTP)

\begin{tabular}{|c|c|c|c|c|c|c|}
\hline WRTP No. & $\mathrm{Z}_{1}$ Score & $\mathrm{Z}_{2}$ Score & $\mathrm{Z}_{3}$ Score & $\mathrm{Z}_{4}$ Score & Comprehensive score & Average score \\
\hline \multirow[t]{4}{*}{$\# 1$} & 2.104 & 4.218 & 0.516 & -0.680 & 1.824 & 0.199 \\
\hline & 0.623 & 0.197 & 0.560 & -1.332 & 0.251 & \\
\hline & -0.294 & -1.811 & -1.363 & 1.334 & -0.550 & \\
\hline & -0.976 & -1.013 & -0.103 & -0.742 & -0.728 & \\
\hline \multirow[t]{4}{*}{$\# 2$} & 4.320 & 0.597 & 0.092 & 0.714 & 2.089 & 0.996 \\
\hline & 2.123 & -1.924 & -0.056 & -0.127 & 0.489 & \\
\hline & 2.079 & -1.874 & 0.826 & -0.386 & 0.557 & \\
\hline & 2.594 & -1.591 & 0.676 & -0.133 & 0.850 & \\
\hline \multirow[t]{4}{*}{$\# 3$} & 0.18 & 1.078 & -0.539 & -0.511 & 0.2 & -0.085 \\
\hline & -0.459 & 0.123 & -0.955 & -0.646 & -0.346 & \\
\hline & -0.71 & 0.75 & -1.44 & 1.308 & -0.188 & \\
\hline & -0.541 & 1.199 & -1.483 & 1.484 & -0.005 & \\
\hline \multirow[t]{4}{*}{$\# 4$} & -3.151 & -0.131 & -0.554 & -1.055 & -1.566 & -1.111 \\
\hline & -2.63 & -0.161 & 1.726 & 0.66 & -0.916 & \\
\hline & -2.79 & -0.163 & -0.462 & -1.44 & -1.442 & \\
\hline & -2.47 & 0.508 & 2.559 & Î.552 & -0.519 & \\
\hline
\end{tabular}

also the degree of water pollution. Overall, these four principal components can have key influences on the reclaimed water quality. It's of great importance to pay attention to the removal efficiency of the involved water quality indices when choosing the wastewater reclamation treatment process.

\subsection{Comparison of Reclaimed Water Quality among Various Treatment Plants}

The component score $\left(Z_{i}\right)$ of each principle component was calculated using Equation (4) and the eigenvector $\left(L_{i}\right)$ in Equation (6). For example, the score $\left(Z_{i}\right)$ of the four principle components can be calculated as follows:

$Z_{1}=0.403 y_{1}+0.402 y_{2}+0.419 y_{3}+0.409 y_{4}+0.039 y_{5}+$ $0.030 y_{6}+0.427 y_{7}+0.120 y_{8}+0.233 y_{9}+0.109 y_{10}+0.261 y_{11}$

$Z_{2}=-0.236 y_{1}-0.085 y_{2}-0.210 y_{3}-0.178 y_{4}+0.002 y_{5}-0.353 y_{6}$

$+0.099 y_{7}-0.212 y_{8}+0.413 y_{9}+0.505 y_{10}+0.506 y_{11}$

$Z_{3}=0.083 y_{1}+0.159 y_{2}-0.043 y_{3}-0.187 y_{4}+0.682 y_{5}+0.467 y_{6}$ $-0.053 y_{7}-0.479 y_{8}+0.100 y_{9}-0.030 y_{10}+0.064 y_{11}$

$Z_{4}=-0.049 y_{1}-0.035 y_{2}+0.060 y_{3}+0.113 y_{4}+0.543 y_{5}-0.103 y_{6}$ $-0.231 y_{7}+0.533 y_{8}-0.302 y_{9}+0.496 y_{10}-0.018 y_{11}$

The comprehensive score of each WRTP was then calculated using Equation (5) with the percentage variance $\left(\mathrm{d}_{\mathrm{i}}\right)$ shown in Table 4 acting as the weighting factor. The average score of the water quality for each WRTP was then obtained, and the results are shown in Table 6 . The comprehensive score value $Z$ of each WRTP could reflect the quality of its reclaimed water, and a lower comprehensive score value can indicate a better reclaimed water quality. It can be found from Table 6 that WRTP \#4 had the best effluent quality that is associated with a least comprehensive score (i.e. -1.111). This plant used the advanced RO process for the reclamation treatment of wastewater, and thus it had a higher removal rate of pollutants. The comprehensive score of WRTP \#2 was the highest (i.e. 0.996), indicating that its effluent quality was the worst. This plant adopted the micro-flocculation process for the reclamation treatment, and thus it had a poor effluent quality. WRTP\#1 used the coagulation, sedimentation, and filtration process for wastewater reclamation, and WRTP \#3 applied ultra-filtration membrane process for reclamation treatment. As a result, their reclaimed water qualities were between those of WRTPs \#2 and \#4. The wastewater reclamation treatment process can have significant impact on the 11 selected water quality indices of reclaimed water due to their different pollutant removal mechanisms (Table 2). This can lead to difficulty in evaluating the overall water quality of each WRTP. The four principle components identified in this study can help evaluate the overall water quality associated with different reclamation treatment process, and should be listed as key monitoring water quality indices during the daily operation of WRTP, and should be controlled based on the application purposes of reclaimed water.

\section{Conclusions}

A principal component analysis (PCA) method was applied to evaluate the reclaimed water quality associated with wastewater reclamation. A series of water quality data, covering eleven parameters, were collected from four typical wastewater reclamation treatment plants (WRTPs) in northern China. In addition to the conventional physicochemical parameters, the measurements of two estrogens in reclaimed water, namely the Di (2-ethylhexyl) phthalate (DEHP) and di-n-butyl phthalate (DBP), were also conducted in this study due to the health safety concerns of wastewater reclamation. Four principal components, accounting for $87.66 \%$ of the variance in the original water quality data set, were identified to comprehensively and objectively reflect the reclaimed water quality. The first principal component (PC) was mainly involved with 
the COD parameter and the sensory properties of reclaimed water, including chroma, turbidity, dissolved solids, and total hardness. The second PC included $\mathrm{NH}_{3}-\mathrm{N}$, DBP, and DEHP, which can indicate the ecological and human health security associated with the reuse of reclaimed water. The parameters of total phosphorus (TP) and iron (Fe) were mainly included in the third PC, and the fourth PC was mainly involved with the dissolve oxygen (DO) parameter. These four principal components can have critical influences on the overall quality of reclaimed water. A comprehensive score of water quality was then obtained for each WRTP. It was observed that the wastewater reclamation process could greatly affect the quality of reclaimed water. The reverse osmosis (RO) process was associated with the best water quality, followed by ultrafiltration membrane process and coagulation-sedimentationfiltration process. The micro-flocculation reclamation process was linked to the worst reclaimed water quality. As a result, the four principle components identified in this study should be listed as the key monitoring indices of WRTP effluent during its daily operation, and their effective control is critical for ensuring the safe utilization of reclaimed water.

Acknowledgments. This work was supported by the Natural Science Foundation of China (No. 51178005). The authors are grateful to the anonymous reviewers for their insightful comments.

\section{References}

Al-Rifai, J.H., Gabelish, C.L., and Schäfer, A.I. (2007). Occurrence of pharmaceutically active and non-steroidal estrogenic compounds in three different wastewater recycling schemes in Australia. Chemosphere, 69(5), 803-815. http://dx.doi.org/10.1016/j.ch emosphere. 2007.04.069

Caldwell, J.C. (2012). DEHP: genotoxicity and potential carcinogenic mechanisms - a review. Mutat. Res./Rev. Mutat., 751(2), 82-157. http://dx.doi.org/10.1016/j.mrrev.2012.03.001

Carr, G., Potter, R.B., and Nortcliff, S. (2011). Water reuse for irrigation in Jordan: Perceptions of water quality among farmers. Agr. Water Manange., 98(5), 847-854. http://dx.doi.org/10.1016/j. agwa t.2010.12.011

Deb, D., Deshpande, V.N., and Das, K.Ch. (2008). Assessment of water quality around surface coal mines using principal component analysis and fuzzy reasoning techniques. Mine Water Environ. 27(3), 183-193. http://dx.doi.org/10.1007/s10230-008-0030-z

Dodd, M.C., Kohler, H.P., and von Gunten, U. (2009). Oxidation of antibacterial compounds by ozone and hydroxyl radical: elimination of biological activity during aqueous ozonation processes. Environ. Sci. Technol., 43(7), 2498-2504. http://dx.doi.org/10.1021 /es8025424

Eaton, A.D., Clesceri, L.S., Rice, E.W., and Greenberg (2005). Standard Methods for the Examination of Water and Wastewater, 21st Edition, Washington, DC: American Public Health Association, American Water Works Association, and the Water Environment Federation.

Furumai, H. (2008). Rainwater and reclaimed wastewater for sustainnable urban water use. Phys. Chem. Earth, Parts $A / B / C, 33(5)$, 340-346. http://dx.doi.org/10.1016/j.pce.2008.02.029

Guimet, F., Ferré, J., Boqué, R., and Rius, F.X. (2004). Application of unfold principal component analysis and parallel factor analysis to the exploratory analysis of olive oils by means of excitationemission matrix fluorescence spectroscopy. Anal. Chim. Acta.,
515(1), 75-85. http://dx.doi.org/10.1016/j.aca.2004.01.008

Iscen, C.F., Emiroglu, O., Ilhan, S., Arslan, N., Yilmaz, V., and Ahiska, S. (2008). Application of multivariate statistical techniques in the assessment of surface water quality in Uluabat Lake, Turkey. Environ. Monit. Assess., 144(1-3), 269-276. http://dx.doi. org/10.1007/s10661-007-9989-3

Kalavrouziotis, I.K., Robolas, P., Koukoulakis, P.H., and Papadopoulos, A.H. (2008). Effects of municipal reclaimed wastewater on the macro-and micro-elements status of soil and of Brassica oleracea var. Italica, and B. oleracea var. Gemmifera. Agr. Water Manange., 95(4), 419-426. http://dx.doi.org/10.1016/j.agwat.2007. 11.004

Kazi, T.G., Arain, M.B., Jamali, M.K., Jalbani, N., Afridi, H.I., Sarfraz, R.A., Baig, J.A., and Shah, A.Q. (2009). Assessment of water quality of polluted lake using multivariate statistical techniques: A case study. Ecotox. Environ. Safe., 72(2), 301-309. http:// dx.doi.org/10.1016/j.ecoenv.2008.02.024

Mandal, U.K., Warrington, D.N., Bhardwaj, A.K., Bar-Tal, A., Kautsky, L., Minz, D., and Levy, G.J. (2008). Evaluating impact of irrigation water quality on a calcareous clay soil using principal component analysis. Geoderma, 144(1-2), 189-197. http://dx.doi.org/ 10.1016/j.geoderma.2007.11.014

Ouyang, Y. (2005). Evaluation of river water quality monitoring stations by principal component analysis. Water Res., 39(12), 2621 -2635. http://dx.doi.org/10.1016/j.watres.2005.04.024

Peiris, R.H., Hallé, C., Budman, H., Moresoli, C., Peldszus, S., Huck, P.M., and Legge, R.L. (2010). Identifying fouling events in a membrane-based drinking water treatment process using principal component analysis of fluorescence excitation-emission matrices. $\mathrm{Wa}$ ter Res., 44(1), 185-194. http://dx.doi.org/10.1016/j.watres.2009.0 9.036

Peldszus, S., Hallé, C., Peiris, R.H., Hamouda, M., Jin, X., Legge, R.L., Budman, H., Moresoli, C., and Huck, P.M. (2011). Reversible and irreversible low-pressure membrane foulants in drinking water treatment: identification by principal component analysis of fluorescence EEM and mitigation by biofiltration pretreatment. Water Res., 45(16), 5161-5170. http://dx.doi.org/10.1016/j.watres. 2011.07.022

Primpas, I., Tsirtsis, G., Karydis, M., and Kokkoris, G.D. (2010). Principal component analysis: Development of a multivariate index for assessing eutrophication according to the European water framework directive. Ecol. Indic., 10(2), 178-183. http://dx.doi. $\operatorname{org} / 10.1016 /$ j.ecolind.2009.04.007

Rusan, M.J.M., Hinnawi, S., and Rousan, L. (2007). Long term effect of wastewaterirrigation of forage crops on soil and plant quality parameters. Desalination, 215(1-3), 143-152. http://dx.doi. org/10. 1016/j.desal.2006.10.032

Sastry, C.A., and Sundaramoorthy, S. (1996). Industrial use of fresh water vis-a-vis reclaimed municipal wastewater in Madras, India. Desalination, 106(1-3), 443-448. http://dx.doi.org/10.1016/ S00119164(96)00145-2

Shrestha, S., and Kazama, F. (2007). Assessment of surface water quality using multivariate statistical techniques: a case study of the Fuji river basin, Japan. Environ. Modell. Softw., 22(4), 464-475. http://dx.doi.org/10.1016/j.envsoft.2006.02.001

Singh, S.P., Azua, A., Chaudhary, A., Khan, S., Willett, K.L., and Gardinali, P.R. (2010). Occurrence and distribution of steroids, hormones and selected pharmaceuticals in South Florida coastal environments. Ecotoxicology, 19(2), 338-350. http://dx.doi.org/ 10. 1007/s10646-009-0416-0

Suzuki, T., Yaguchi, K., and Suzuki, S. (2001). Monitoring of phthalic acid monoesters in river water by solid-phase extraction and GC-MS determination. Environ. Sci. Technol., 35(18), 3757- 3763. http://dx.doi.org/10.1021/es001860i 
Tomšíková, H., Aufartová, J., Solich, P., Nováková, L., Sosa-Ferrera, Z., and Santana-Rodríguez, J.J. (2012). High-sensitivity analysis of female-steroid hormones in environmental samples. Trac.-Trend. Anal. Chem., 34, 35-58. http://dx.doi.org/10.1016/j.trac.2011.11.0 08

Toze, S. (2006). Reuse of effluent water - benefits and risks. Agr. Water Manage., 80(1-3), 147-159. http://dx.doi.org/10.1016/j.agwat. 2005.07.010

Wang, F., Wang, X., Zhao, Y., and Yang, Z.F. (2012). Long-term water quality variations and chlorophyll a simulation with an emphasis on different hydrological periods in Lake Baiyangdian, northern China. J. Environ. Inform., 20(2), 90-102. http://dx.doi.org/ $10.3808 /$ jei.201200223

Wei, D., Tan, Z., and Du, Y. (2011). A biological safety evaluation on reclaimed water reused as scenic water using a bioassay battery. $J$. Environ. Sci., 23(10), 1611-1618. http://dx.doi.org/10.1016/S10010742(10)60631-6

Yanko, W.A., Jackson, J.L., Williams, F.P., Walker, A.S., and Castillo, M.S. (1999). An unexpected temporal pattern of coliphage isolation in groundwaters sampled from wells at varied distances from reclaimed water recharge sites. Water Res., 33(1), 53-64. http://dx. doi.org/10.1016/S0043-1354(98)00193-6

Yi, L., Jiao, W., Chen, X., and Chen, W. (2011). An overview of reclaimed water reuse in China. J. Environ. Sci., 23(10), 15851593. http://dx.doi.org/10.1016/S1001-0742(10)60627-4

Yin, R., Lin, X.G., Wang, S.G., and Zhang, H.Y. (2003). Effect of DBP/DEHP in vegetable planted soil on the quality of capsicum fruit. Chemosphere, 50(6), 801-805. http://dx.doi.org/10.1016/ S00 45- 6535(02)00222-9

Zhang, X., Zhao, X., Zhang, M., and Wu, Q. (2011). Safety evaluation of an artificial groundwater recharge system for reclaimed water reuse based on bioassays. Desalination, 281, 185-189. http:// dx.doi.org/10.1016/j.desal.2011.07.060

Zhang, Y., Guo, F., Meng, W., and Wang, X.Q. (2009). Water quality assessment and source identification of Daliao river basin using multivariate statistical methods. Environ. Monit. Assess., 152(1-4), 105-121. http://dx.doi.org/10.1007/s10661-008-0300-z

Zhao, Y., Xia, X.H., Yang, Z.F., and Xia, N. (2011). Temporal and spatial variations of nutrients in Baiyangdian Lake, North China. $J$. Environ. Inform., 17(2), 102-108. http://dx.doi.org/10.3808/jei.20 1100192

Zheng, C., Yang, W., and Yang, Z.F. (2011). Strategies for managing environmental flows based on the spatial distribution of water quality: a case study of Baiyangdian Lake, China. J. Environ. Inform., 18(2), 84-90. http://dx.doi.org/10.3808/jei.201100202 